\title{
Improvement on Mechanical Properties of Fresh and Hardened Concrete by Marble Waste and Pumicite
}

\author{
SrijaJuluru, R. Sanjaykumar, Adarsh, Ajith, K SShiyas Ismail
}

\begin{abstract}
Development, world-over is fuelled by growth of the economy and the growth of economy is fuelled by growth in infrastructure. Estimates record a consumption of 6.6 Gigatonnes of concrete in China in earlier part of this decade, for infrastructure development. But today the world is poised on a tipping point environmentally, and sustainable growth is the need of the hour. This requirement is leading to research in replacement of energy intensive materials, along with capture and utilization of available waste. Marble powder waste which has deleterious impact on environment is one such material. Existing literature majorly focus on utilization of marble powder as fine aggregates in concrete. This study aims to study the suitability of marble powder as a filler material and as a replacement of cement. Pumice breccias are used as coarse aggregates. Experimental investigations were conducted to ascertain the compressive and split tensile strength in concrete with marble powder replacing cement by various percentages. The results indicate a general improvement in both compressive and split tensile strength.
\end{abstract}

Keywords : Pumices, Marble Dust, Compressive, Flexural

\section{INTRODUCTION}

Concrete and steel are literally the building blocks of modern civilization and development. A strong and positive correlation is observed between economic growth and consumption of these materials. Parallel to this economic narrative of growth, runs the degradation of ecosystems and environment. Thus developing nations, are challenged to route their country's growth on a sustainable path. It is hence imperative to lower the ecological footprint of concrete by reducing consumption of new resources and utilizing waste materials generated in other processes. The utilization of LWA concrete has numerous focal points such as decrease of dead load, high warmthprotection and lowering haulage and handling cost. LWA comprises of natural and artificial aggregates. Pumice stones are used in this study.

Revised Manuscript Received on December 30, 2019.

* Correspondence Author

Srija Juluru, Assistant Professor, Department of Civil Engineering, Aarupadai Veedu Institute of Technology Chennai, India.

Email: jsrija26@gmail.com

R. Sanjay kumar, Assistant Professor, Department of Civil Engineering, Aarupadai Veedu Institute of Technology Chennai, India.

Email: sanjay..civil@avit.ac.in

Adarsh, Graduate student, Department of civil Engineering, Aarupadai Veedu Institute of Technology, Chennai, Emailadarsh@gmail.com

Ajith, K S, Graduate student, Department of civil Engineering, Aarupadai Veedu Institute of Technology, Chennai, India. Email:Ajthks@gmail.com Shiyas IsmailS, Graduate student, Department of civil Engineering, Aarupadai Veedu Institute of Technology, Chennai, India Shiyaz@gmail.com

(C) The Authors. Published by Blue Eyes Intelligence Engineering and Sciences Publication (BEIESP). This is an open access article under the CC BY-NC-ND license (http://creativecommons.org/licenses/by-nc$\underline{\mathrm{nd} / 4.0 / \text { ) }}$
These LW concrete have a unit weight ranges from 350 to $1900 \mathrm{~kg} / \mathrm{m} 3$.This study investigates partial replacement of cement with waste marble powder, concurrently with pumice LA in concrete..Lokesh.S et.al (2013) had investigated work on LWC with silica fume and HVFA and concluded the tests on hardened concrete increases by using mineral admixtures.Sudarshan Raj P etal (2017) had conducted research and results shown that $10 \%$ is optimum for marble waste powder, $15 \%$ for coconut shells, $25 \%$ for quarry dust replacement are suitable alternative materials for cost reduction in construction.N Venkata Ramana (2015) had done his eork on basic properties of pumiicties and concluded the suitable percentage of $15 \%$ in concrete and regression model was created for both compressive and split tensile

\section{MATERIALS AND METHODOLOGY}

\section{A. Marble Dust}

Marble powder dust was acquired during cutting and processing of marble slabs from production lines and its synthetic structure is tabulated in fig 1

Table 1 Chemical composition of marble powder

\begin{tabular}{|l|l|}
\hline Constituent & percentage \\
\hline $\mathrm{SiO}_{2}$ & 61 \\
\hline $\mathrm{Al}_{2} \mathrm{O}^{3}$ & 18.4 \\
\hline $\mathrm{Fe}_{2} \mathrm{O}^{3}$ & 06.00 \\
\hline $\mathrm{CaO}$ & 04.5 \\
\hline $\mathrm{MgO}$ & 2.5 \\
\hline $\mathrm{Na}_{2} \mathrm{O}$ & $\mathrm{Nil}$ \\
\hline $\mathrm{K}_{2} \mathrm{O}$ & 03.02 \\
\hline
\end{tabular}

Various marble tests and results

a) Consistency of marble $=22 \%$

b) Specific gravity $=2.19$

c) Specific surface area $=2400 \mathrm{~cm} 2 / \mathrm{gm}$

B. Cement

For the present investigation, OPC 53grade confirming to BIS : 12269-19879 [4 ]was used.

Initial setting time of cement $=33$ rninutes

Final setting time of cement $=8 \mathrm{hrs} 20 \mathrm{~min}$

Consistency $=33 \%$

Specific gravity $=3.01$

\section{Fine Aggregate}

Sand going through IS $4.75 \mathrm{~mm}$ Sieve was utilized for all samples. The physical properties of sand are tested. Its specific gravity is obtained as 2.741.Fineness modulus as 2.6 and water absorption as $0.9 \%$ 
Improvement on Mechanical Properties of Fresh and Hardened Concrete by Marble Waste and

Pumicite

\section{Coarse Aggregate}

For experimental work pumice stone is utilized collected from Nellore.

Table 2 Preliminary Tests for coarse aggregates

\begin{tabular}{|r|l|l|}
\hline S.No & Preliminary Tests & Result Value \\
\hline 1. & Specific gravity & 0.9 \\
\hline 2. & Water Absorption & $29 \%$ \\
\hline 3. & Flakiness Index & $3.6 \%$ \\
\hline 4. & Elongation Index & $5 \%$ \\
\hline 5. & Impact Test & $35 \%$ \\
\hline
\end{tabular}

$\mathrm{E}$ potable water is utilized for work which is free from impurities

\section{METHODOLOGY}

Cement was partially replaced by marble powder and pumice stone as coarse aggregate in concrete. Marble waste product are mixed in concrete mix M-25in different percentage $(5 \%, 10 \%$,

15\%,20\%) by weight. After curing (7 and 28 days), cubes, cylinders, beams were tested and compared with conventional

concretePrewetting of aggregate is achieved before concreti ng dueto the high water absorption property of pumice light weight. A wetted product lasting 24 hours is removed and moisture is washedout.The mix ratio is calculated based upon IS10262:2009[6] to obtain the volume of cement,fine,coarseaggregates.The corresponding proportion of the combination is as follows.For control concrete the mix design is $1: 1.2: 2.25$ with a Water/Cement ratio of 0.496 and for LWC the mix design ratio is 1:1.45:0.65:0.41.

\section{RESULTS AND DISCUSSIONS}

\section{A. Test On Fresh Concrete}

To determine Slump value for normal and concrete with marble powder and pumices. The following workability tests are conducted.

1) Slump test

2) Compaction factor test

Table 3: Results of workability tests

\begin{tabular}{|c|c|c|c|c|c|c|}
\hline & \multirow{2}{*}{$\begin{array}{c}\text { Test for } \\
\text { Workability }\end{array}$} & $\begin{array}{c}\text { Conventional } \\
\text { Concrete }\end{array}$ & \multicolumn{4}{|c|}{$\begin{array}{c}\text { Replacement (\%) by } \\
\text { marble powder and } \\
\text { pumice in concret }\end{array}$} \\
\cline { 4 - 7 } & & 74 & 70 & 68 & 65 & 61 \\
\hline 2 & Slump Cone & 0.9 & 0.8 & 0.81 & 0.83 & 0.84 \\
\hline
\end{tabular}

\section{B. Tests for Compressive strength}

Cubical test specimens of size $150 \mathrm{mmx} 150 \mathrm{mmx} 150 \mathrm{~mm}$ were cast and tested for compressive strength in compliance to Indian standards. Twenty cubes with varying percentage of marble powder were tested to determine the strength after seven and twenty eight days of curing. The results are presented in Fig. 1.
The aggregate used in this investigation is $20 \mathrm{~mm}$ down size crushed aggregate and angular in shape dressed thoroghly .As per IS Specifications[5] preliminary tests were done and results are tabulated in table 2

\section{Tests for Split tensile strength}

Cylindrical test specimens of $150 \mathrm{~mm}$ diameter and 300 $\mathrm{mm}$ height were prepared to evaluate split tensile strength. Twenty cylinders with varying percentage of marble powder were tested to determine the strength after seven and twenty eight days of curing. The results are presented in Fig. 2.

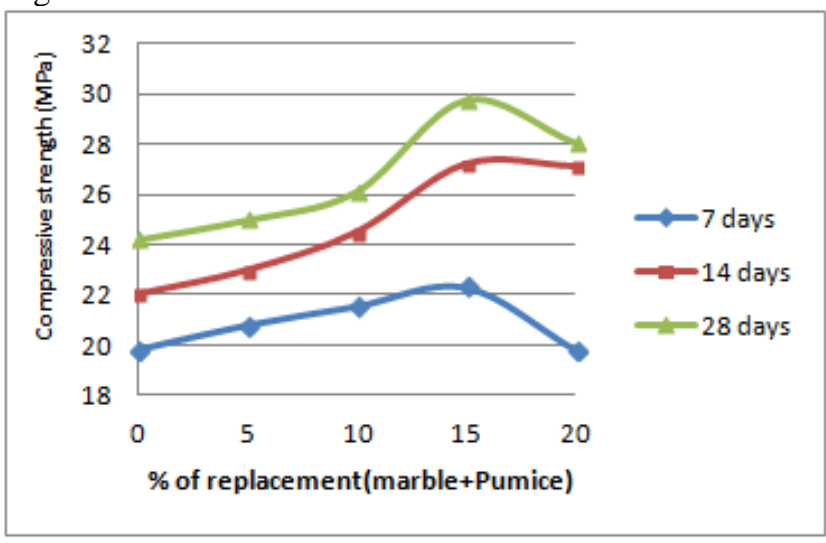

Fig.1 Results for compressive strength

The tensile strength decreases with decrease in replacement percentage. At $15 \%$ RMP, a 45.5\% improvement in tensile strength is observed after 7 days of curing, when compared with conventional concrete. In case of RMP $10 \%$, the 7 days strength is found to be $3.2 \mathrm{~N} / \mathrm{mm} 2$ which is $55.5 \%$ higher than conventional concrete strength after 28 days of curing.

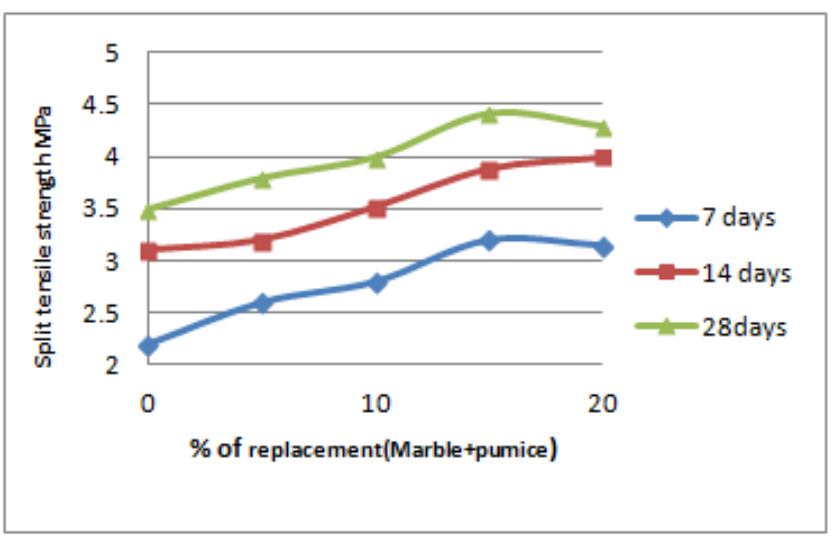

Fig.2 Split tensile strength results

\section{Tests for Acid Attack test}

To determine performance in corrosive environments, acid resistance test was performed. The study involves determination of compressive strength, after exposure of a sample of standard size to $5 \%$ sulphuric acid for 15 days. The results are tabulated in Table 3 . 
Table 3: Results on acid attack

\begin{tabular}{|l|l|l|}
\hline S.No & $\begin{array}{l}\text { Replacement(marble } \\
\text { waste+pumicite)\% }\end{array}$ & $\begin{array}{l}\text { Compressive } \\
\text { strength MPa }\end{array}$ \\
\hline 1 & 0 & 22.00 \\
\hline 2 & 5 & 22 \\
\hline 3 & 10 & 23.5 \\
\hline 4 & 15 & 27.8 \\
\hline 5 & 20 & 26.25 \\
\hline
\end{tabular}

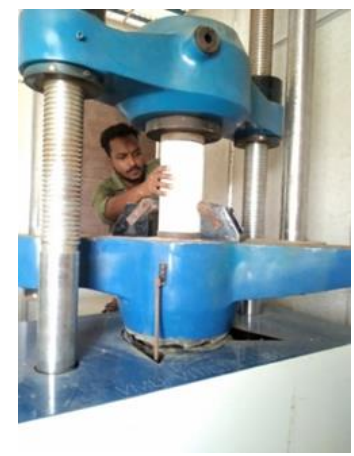

Fig.3 Testing on cylinders

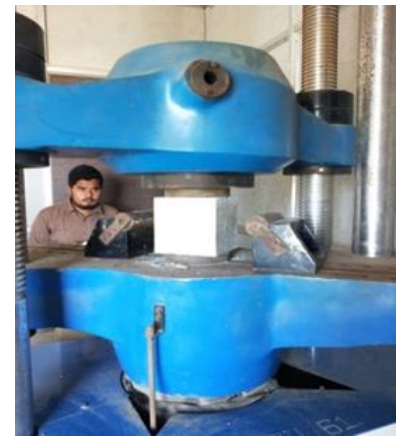

Fig.4 Testing on cubes

\section{E. Flexural Strength}

Flexural strength of different concrete mixes were determined by testing 500x500x100 unreinforced prismatic specimens.as perIS456. The specimens were subjected to two point loading. Deflection was recorded in middle of the beam using a dial gauge. The specimens were tested after 7, 14 and 24 days of curing. Optimal percentage of pumicite and marble waste in concrete is obtained. The results are presented in table 4 .

Table 4 Flexural strength of prismatic specimens

\begin{tabular}{|l|l|l|l|l|}
\hline $\begin{array}{l}\text { S. } \\
\text { No }\end{array}$ & $\begin{array}{l}\text { Replaceme } \\
\text { nt(marble } \\
\text { waste+pu } \\
\text { micite)\% }\end{array}$ & $\begin{array}{l}\text { 7days( } \\
\text { MPa) }\end{array}$ & $\begin{array}{l}\text { 14days } \\
\text { (MPa) }\end{array}$ & $\begin{array}{l}\text { 28days } \\
\text { (MPa) }\end{array}$ \\
\hline 1 & 0 & 2.94 & 3.65 & 4.32 \\
\hline 2 & 5 & 3.05 & 4.17 & 5.05 \\
\hline 3 & 10 & 3.2 & 4.23 & 5.10 \\
\hline 4 & 15 & 3.67 & 4.38 & 5.59 \\
\hline 5 & 20 & 3.56 & 4.25 & 5.41 \\
\hline
\end{tabular}

\section{CONCLUSION}

It can be seen from the results of this study that use of marble dust replacement of cement in the production of concrete for the construction industry should be encouraged where there comparative cost advantage, the following conclusions can be made from this study

- Replacement of cement with marble powder and coarse aggregate with pumicite, is observed to improve the mechanical properties of concrete. This improvement is obtained upto $15 \%$ of replacement after which there is marked deterioration in properties.

- The optimum percentage of replacement is determined to be $15 \%$.

- Thus we can conclude that At 7 and 28 days after testing $15 \%$ replacement of pumicite and marble there is $14 \%$ increment in compressive strength when compared with control concrete

- Pumicite absorbs more than $20 \%$ water by weight, and this reduces workability of concrete with increasing percentage of replacement. At $15 \%$ the workability is 65 , which can be practically used.

-. Due to fineness and pozzolanic nature of marble powder, it behaves as mineral admixture thus improving concrete strength. Usage of pumicite stones results better strength to weight properties of concrete.Thus the concrete using marble powder as filler and pumicite as coarse aggregate will be useful high strength low weight applications such as prefabricated girders, dynamic structures

\section{REFERENCES}

1. S.Lokesh,M.G.RanjithKumarand S.Loganathan,"Effective utilization of high volume flyashwithlight weight aggregate in concrete for construction industry", International journal of advancedstructures and geotechnical engineering,vol2,No04,pp142$146,2013$.

2. Sudarshan Raj P,Chinnaswamy.M,Thenmozhi.S"Experimental study on concrete by partial replacement of marble dust powder with cement,quarry dust with fine aggregate,and coconut shell with coarse aggregate",International Journal Of Emerging Technology in Computer Science and Electronics,vol 24,issue 7 april 2017.

3. N Venkata Ramana "Behaviour of pumicitelight weightconcrete"Imternational Journal of Applied research innscience and engineering

4. IS: 12269-1987, "Specification for 53 grade Ordinary Portland Cement", Bureau of IndianStandard.

5. IS 383-1970, "Specifications for Coarse and Fine Aggregates from Natural Sources for Concrete" (Second Revision), Bureau of Indian Standard

6. Bis:10262-2009, "Concrete mix proportioning- guidelines," Bureau of Indian Standards

7. . IS 516-1979, "Method of Tests for Strength of Concrete", Bureau of Indian Standard

8. IS 456-2000, "Code of Practice for Plain and Reinforced Concrete Structures", Bureau of IndianStandard

9. D. S. Vijayan, Dineshkumar, S. Arvindan et al., Evaluation of ferrock: A greener substitute to cement, Materials Today: Proceedings, https://doi.org/10.1016/j.matpr.2019.10.147.

10. S.Aravindan, D.S.Vijayan, K.Naveen Kumar, B.Saravanan, Characteristic Study of Concrete by Replacing Glass Cullet and Ceramic Tiles over Conventional Aggregates, International Journal Of Scientific \& Technology Research, Volume 8, Issue 10, OCTOBER 2019, Page no - $1802-1805$.

11. D.S.Vijayan ,J. Revathy,Flexural Response of Fibre Reinforced Polymer Laminated Pre-stressed Concrete Beams, Indian Journal of Science and Technology, Vol 9(42), DOI: 10.17485/ijst/2016/v9i42/101824, November 2016 
Improvement on Mechanical Properties of Fresh and Hardened Concrete by Marble Waste and Pumicite

\section{AUTHORS PROFILE}

SrijaJulurucurrently working in AVIT.Completed M.Tech Structures from SRM University.She is doing her research on Steel Structures

Sanjay Kumar completed his M.Tech at Vallimalai engineering college, affiliated to Anna University. He is currently working as Assistant Professor in AVIT.

Adarsh, completed his B.E. from AVIT college in 2019.

Ajith, completed his B.E. from AVIT college in 2019.

K.S. ShiyasIsmail, pcompleted his B.E. from AVIT college in 2019. . 